\title{
ETNOBOTANI PEKARANGAN RUMAH INAP (HOMESTAY) DI DESA WISATA TAMBAKSARI, PURWODADI, PASURUAN, JAWA TIMUR
}

\author{
Eka Oktavianti ${ }^{1}$, Luchman Hakim ${ }^{2}$ \\ ${ }^{1}$ Mahasiswa Jurusan Biologi, Fakultas Matematika dan Ilmu Pengetahuan Alam, Universitas Brawijaya, Malang \\ Jurusan Biologi, Fakultas Matematika dan Ilmu Pengetahuan Alam, Universitas Brawijaya, Malang
}

\begin{abstract}
Abstrak
Penelitian ini bertujuan untuk mengetahui jenis-jenis tanaman pekarangan rumah, menggali persepsi masyarakat dan wisatawan tentang tanaman pekarangan, mengetahui nilai kegunaan tanaman pekarangan homestay, serta mengetahui periodesitas masa panen dan berbunga tanaman di Desa Wisata Tambaksari. Metode yang dilakukan pada penelitian ini, meliputi survei tanaman pekarangan rumah, studi persepsi masyarakat dan wisatawan dengan membagi kuisoner pada 60 responden. Nilai kegunaan tanaman dianalisis menggunakan metode UVs, sedangkan nilai ketergantungan masyarakat terhadap suatu tanaman dianalisis dengan metode ICS, serta membuat tabel periodesitas masa panen dan berbunga tanaman pekarangan rumah. Berdasarkan hasil penelitian terdapat 43 jenis tanaman di pekarangan rumah. Persepsi responden homestay lebih tinggi dibandingkan responden non-homestay terhadap desa wisata dan pekarangan rumah. Wisatawan memandang bahwa tanaman pekarangan rumah sangat penting untuk kegiatan ekowisata. Hasil analisis nilai UVs dari 43 tanaman diketahui bahwa Musa acuminata var Berlin, Musa (Kelompok AA) Sucrier, Musa (Kelompok AAA) Gros Michael, dan Musa acuminata var Hijau memiliki nilai UVs tertinggi dengan nilai sebesar 5. Sedangkan, analisis nilai ICS dari 43 jenis tanaman diketahui bahwa Cocos nucifera L. memiliki nilai ICS tertinggi dengan nilai sebesar 84. Analisis ICS dan UVs dapat digunakan untuk menggali persepsi tentang etnobotani pekarangan rumah dalam mempertahankan biodiversitas pekarangan rumah dan fungsi ekologis lingkungan. Tabel periodesitas masa panen dan masa berbunga dapat mempermudah wisatawan saat melakukan kegiatan ekowisata di Desa Wisata tambaksari.
\end{abstract}

Kata Kunci: Desa wisata, ICS, pekarangan rumah, persepsi, UVs

\begin{abstract}
The research aimed to know species in home garden, study perception local people and tourism about home garden plants, and knew using values plant in homestay garden at Tambaksari tourism village. Methods in the research used survey home garden plants, local people and tourism perception with questionnaires techniques to 60 people. Using values plants were analysed by UVS methods, while society reliance values to plants were analysed by ICS methods, with made period haverst and blooming plants home garden table. Results of the study showed that 43 species in home garden. Local people homestay had better perceptions than different local people non homestay about tourism village andhome garden. Tourism perception showed that home garden plant very important for ecotourism. UVs values analysis result from 43 plants were known that Musa acuminata var Berlin, Musa (Kelompok AA) Sucrier, Musa (Kelompok AAA) Gros Michael, and Musa acuminate var Hijau had the highest UVs values with 5 values. ICS analysis got Cocos nucifera L.with 84 values.ICS and UVs analysis can be used to excavate the perception about ethnobotany home garden to protect home garden diversity and ecological function to environment. Period haverst and blooming plants home garden table get easier tourism for ecotourism at Tambaksari ecotourism village.
\end{abstract}

Keyword: Tourism village, ICS, Home garden, Perception, UVs

\section{PENDAHULUAN}

Ekowisata merupakan suatu kegiatan wisata yang konsep utamanya difokuskan terhadap kelestarian sumberdaya pariwisata. Perjalanan ekowisata lebih difokuskan pada

Corresponding Address:

Eka Oktavianti

Email : eka_oktavianti@yahoo.com

Address : Biology Undergraduate Program, Biology

Department, Faculty of Mathematics and Natural

Sciences, Brawijaya University, Jl. Veteran, Malang wisata alam yang bertanggung jawab dengan cara mengkonservasi lingkungan dan meningkatkan kesejahteraan masyarakat lokal. Akhir dari perjalanan ekowisata diharapkan para pengelola dan wisatawan dapat mengelola sumber wisata alam secara ramah lingkungan [3]. Kegiatan ekowisata dapat dilakukan di daerah yang memiliki potensi sumber daya alam. Salah satunya adalah daerah pedesaan yang masih alami dengan sumber daya desa yang dimiliki, sehingga dapat menunjang kegiatan ekowisata. 
Suatu pedesaan akan memiliki potensi sumber daya desa yang berbeda-beda. Terdapat bermacam-macam sumber desa yang dapat dioptimalkan, misalnya adalah kebudayaan lokal, tanaman lokal, dan pekarangan rumah. Menurut Damanik dan Helmut (2006) Indonesia memiliki potensi kawasan ekowisata yang cukup besar. Daerah tersebut tersebar di darat (dalam kawasan konservasi) maupun di laut (dalam bentuk taman nasional laut) [3]. Berdasarkan potensi beragam yang dimiliki oleh Indonesia, dapat menarik minat wisatawan domestik maupun mancanegara. Pengembangan potensi perlu dilakukan dalam pelaksanaan ekowisata untuk meningkatkan keberagaman atraksi wisata yang dimiliki.

Kegiatan ekowisata yang dilakukan di daerah pedesaan, biasanya memberikan atraksi wisata berupa kebudayaan lokal yang berhubungan dengan penggunaan tanaman lokal. Sehingga, wisatawan dapat melihat atraksi wisata berupa pemanfaatan tanaman lokal yang tumbuh di daerah pedesaan. Tanaman lokal biasanya ditanam oleh masyarakat di pekarangan rumah sebagai penghasilan sampingan. Hasil dari pekarangan rumah dapat dimanfaatkan sebagai kebutuhan pangan dan konservasi pendidikan bagi wisatawan di desa wisata. Menurut Hakim dan Nakagoshi (2007) pekarangan rumah merupakan bagian integral dari sistem pertanian, di mana tanaman yang dipilih berdasarkan jenis tanaman yang ditanam dan dikelola untuk melayani beberapa fungsi seperti kebutuhan medis, tanaman hias, dan tanaman yang menghasilkan produk untuk penghasilan tambahan penduduk [4].

Pekarangan rumah memiliki beberapa peran salah satunya adalah peran ekonomi dan sosial. Peran ekonomi sendiri dari pekarangan rumah adalah adanya pendapatan dari pengelolaan pekarangan rumah yang bervariasi. Cara perawatan tradisional tersebut merupakan pengalaman yang turun temurun dari nenek moyang [1]. Sehingga, pemilik pekarangan rumah tidak memerlukan pelatihan khusus untuk merawat pekarangan rumahnya.

Tanaman pekarangan rumah yang ditanam masyarakat lokal dengan keanekaragaman yang tinggi dapat memberi nilai konservasi sepanjang jalur wisata desa. Desa Wisata Tambaksari adalah salah satu desa wisata yang menggunakan konsep ekowisata dalam pelaksanaannya. Desa ini dijadikan sebagai desa wisata karena, memiliki potensi sumber daya desa yang dapat dikembangkan sebagai atraksi wisata desa. Potensi yang dimiliki oleh Desa Wisata Tambaksari dapat menunjang optimalisasi sumber daya desa sebagai atraksi wisata. Berdasarkan beberapa sumber daya desa, pekarangan rumah adalah salah satu bagian dalam Desa Wisata Tambaksari yang dapat dijadikan sebagai atraksi wisata.

Keanekaragaman tanaman pekarangan rumah yang cukup tinggi tersebut juga dapat meningkatkan kualitas lingkungan homestay yang berada di Desa Wisata Tambaksari. Homestay merupakan salah satu fasilitas yang diberikan untuk wisatawan sebagai tempat penginapan selama wisatawan melakukan kegiatan ekowisata. Kualitas lingkungan homestay yang baik dapat memberikan kepuasan tersendiri bagi wisatawan dan dapat digunakan sebagai wahana pendidikan, serta meningkatkan kualitas lingkungan sekitar. Kebanyakan dari pekarangan rumah yang dimiliki oleh masyarakat Desa Wisata Tambaksari belum diketahui keanekaragaman tanamannya.

Tujuan dari penelitian ini adalah untuk menggali persepsi masyarakat dan wisatawan tentang pemanfaatan tanaman pekarangan homestay sebagai atraksi wisata, dan mengetahui nilai kegunaan tanaman 4 pekarangan homestay, serta mengetahui periodesitas masa panen dan masa berbunga tanaman di Desa Wisata Tambaksari.

\section{METODE}

Desa Wisata Tambaksari telah dijadikan desa wisata sejak 31 Juli 2010, yang diresmikan oleh Dinas Pariwisata Pasuruan. Desa Wisata Tambaksari merupakan suatu desa yang terletak di Kecamatan Purwodadi Kabupaten Pasuruan, Jawa Timur, dan terbagi menjadi empat dusun yaitu, Dusun Krai, Ampelsari, Gunungmalang, dan Tambakwatu dengan jumlah penduduk 4.593 jiwa. Desa Wisata Tambaksari terletak pada ketinggian 550-1000 m dpl dan terletak pada LS 46'30" - 48'00" dan BT 38'00" - 41'30, serta merupakan jalur utama pendakian Gunung Arjuna.

Pendataan tanaman dilakukan dengan cara mendatangi pekarangan homestay dan non homestay untuk mengetahui keragaman tanaman yang terdapat dalam pekarangan rumah. Semua jenis tanaman yang berada di pekarangan rumah akan dicatat, dikarenakan tanaman pekarangan rumah diharapkan nantinya digunakan sebagai atraksi wisata desa. Data tanaman yang diperoleh akan digunakan untuk analisis metode UVs dan ICS. Selain itu, 
pendataan juga dilakukan dengan wawancara semiterstruktur dengan warga desa yang memiliki pekarangan homestay, non-homestay, dan wisatwan. Wawancara dilakukan untuk mengetahui nilai penting tanaman pada kehidupan warga desa dan para wisatawan.

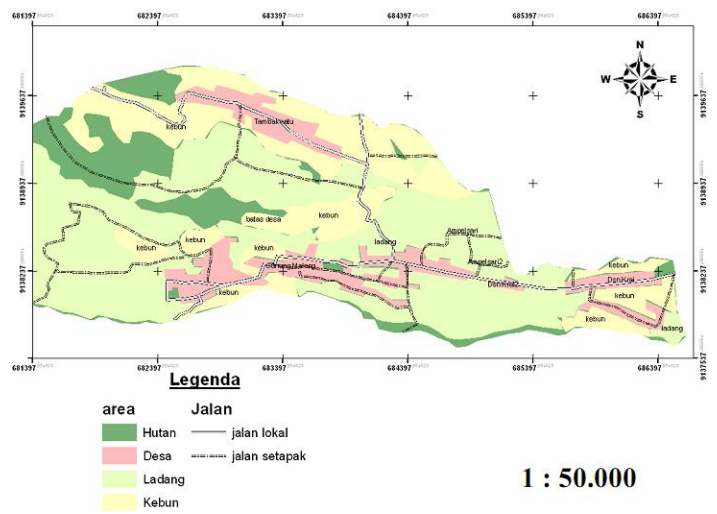

Gambar 1. Peta Desa Wisata Tambaksari

Tanaman yang tidak diketahui namanya, akan diidentifikasi lebih lanjut di Laboratorium Taksonomi Tumbuhan, Fakultas Matematika dan Ilmu Pengetahuan Alam, Universitas Brawijaya.

\section{HASIL DAN PEMBAHASAN}

\section{Pengelolaan Desa Wisata}

Daya tarik ekowisata lainnya adalah masyarakat dan tanaman lokal yang berada di kawasan, sehingga banyak wisatawan yang datang untuk melihat dan mempelajari kebudayaan masyarakat lokal dan mengetahui manfaat tanaman lokal.

Berdasarkan data LADEWIsari diketahui bahwaSetiap tahunnya Desa Wisata Tambaksari menerima kegiatan ekowisata dimulai dari tahun 2010. Wisatawan yang datang juga beragam, dari wisatawan domestik maupun mancanegara. Wisatawan yang datang merupakan wisatawan yang melakukan kegiatan ekowisata untuk lebih mengenal kehidupan pedesaan dan lingkungan sekitar.

Berdasarkan hasil wawancara dengan responden homestay dan non-homestay, diperoleh nilai yang berbeda antara keduanya. Pendapatan responden homestay diwakili dengan nilai sebesar 4,12. Nilai tersebut menyatakan bahwa pendapatan warga homestay meningkat. Sedangkan, hasil wawancara yang dilakukan pada responden nonhomestay diperoleh jawaban dengan nilai sebesar 3,32. Nilai tersebut menyatakan bahwa pendapatan warga non-homestay tidak mengalami perubahan atau tetap. Terdapat perbedaan nilai dalam pendapatan responden homestay dan non homestay, setelah Desa Tambaksari menjadi desa wisata (Gambar 2).

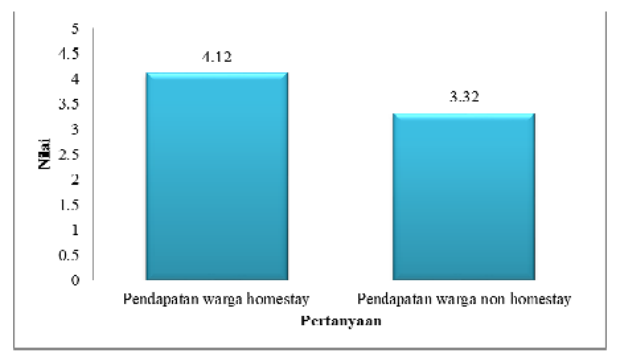

Keterangan: nilai $1<\mathrm{x}<1,8=$ sangat tidak meningkat, $1,81<\mathrm{x}<2,6=$ tidak meningkat $2,61<x<3,4=$ cukup, $3,41<x<4,2=$ meningkat,
$4,21<x<5=$ sangat meningkat

Gambar 2. Perbandingan Pendapatan Responden Homestay dan Non Homestay di Desa Wisata Tambaksari

\section{Presepsi Masyarakat Terhadap Pekarangan Rumah}

Hasil kuisioner pengetahuan responden homestay tentang pekarangan rumah mendapat nilai sebesar 4,52. Nilai tersebut menunjukkan bahwa responden sangat mengetahui apa yang dimaksud dengan pekarangan rumah. Pernyataan yang sama disebutkan oleh responden non homestay. Namun untuk nilai yang didapatkan hanya sebesar 3,84 dibawah nilai yang didapatkan dari responden homestay (Gambar 3). Nilai 3,84 menunjukkan bahwa responden mengetahui apa yang dimaksud dengan pekarangan rumah. Perbedaan nilai yang didapatkan antara responden homestay dan non homestay, dikarenakan responden non homestay kurang berani dalam menjawab pertanyaan yang diajukan. Sehingga, terdapat keragu-raguan untuk menyatakan alasan pada pertanyaan. Hasil persepsi masyarakat terhadap pekarangan rumah secara keseluruhan dapat dilihat pada Gambar 3.

Hasil analisis kuisioner tentang kondisi pekarangan rumah yang dimiliki responden homestay dan responden non-homestay mendapat nilai berturut-turut 3,76 dan 3,44. Kedua nilai tersebut menyatakan bahwa responden memiliki pekarangan rumah dengan kondisi yang terawat. Pekarangan rumah dikatakan terawat apabila tidak adanya sampah non organik di dalam pekarangan rumah, serta gulma dibersihkan kurang lebih tiga sampai empat minggu sekali. Kebiasaaan baik yang dilakukan oleh warga desa adalah membuat tempat pembuangan sampah dibelakang rumah, sehingga sampah tidak berserakan. 


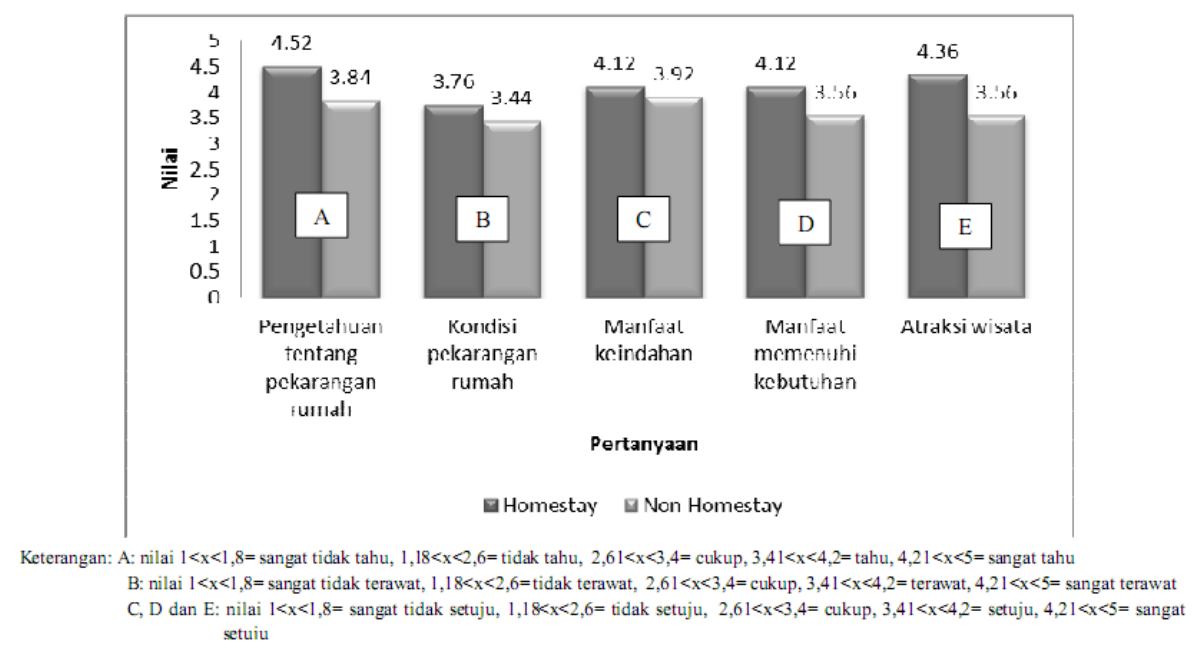

Gambar 3. Nilai Persepsi Masyarakat Homestay dan Non Homestay Terhadap Pekarangan Rumah di Desa Wisata Tambaksari

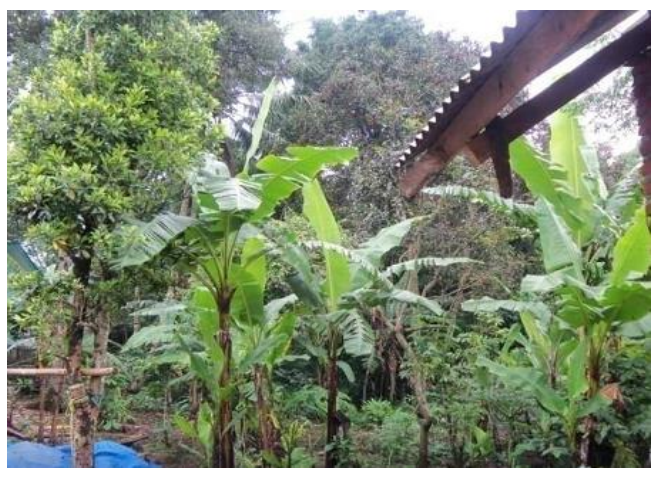

Gambar 4. Kondisi Pekarangan rumah di Desa Wisata Tambaksari

Menurut responden homestay apabila hasil dari pekarangan rumah dijadikan sebagai pemenuhan kebutuhan wisatawan, itu sangat baik dikarenakan dapat membuat makanan dari hasil pekarangan. Selain itu dapat mengenalkan jenis-jenis makanan yang dibuat dari tanaman pekarangan di Desa Wisata Tambaksari. Pernyataan terakhir hampir sama dengan pernyataan yang didapatkan dari responden nonhomestay. Namun terdapat juga responden nonhomestay yang menyatakan bahwa hasil pekarangan tidak harus diberikan pada wisatawan karena itu dirasa kurang baik untuk menjamu wisatawan yang datang ke Desa Wisata Tambaksari.

Keanekaragaman tanaman pekarangan rumah yang lebih banyak dapat memberi fungsi ekologis bagi lingkungannya. Keanekaragaman tanaman pekarangan rumah yang lebih banyak dapat memberi fungsi ekologis bagi lingkungannya. Sebagaian besar adalah tanaman kopi (Coffea arabica), jenis kopi ini banyak ditanam oleh responden karena memiliki kualitas yang baik dan merupakan komoditas utama hasil kebun di Desa Wisata Tambaksari.

Selain tanaman kopi didapatkan pula tanaman pisang, terdapat beberapa jenis pisang yang ditanam oleh responden. Jenis pisang tersebut adalah pisang berlin, pisang emas, pisang ambon, dan pisang hijau. Tanaman pangan lain yang ditanam adalah cengkeh, durian, nanas, singkong, talas, mbote, jagung dll. Tanaman obat yang ditanam adalah tanaman toga berupa kunyit, jahe putih, dan A B 34 temulawak. Tanaman hias yang terdapat di pekarangan rumah homestay adalah bunga mawar, bunga sepatu, dan lidah mertua. Tanaman pakan ternak yang banyak ditanam oleh responden adalah rumput gajah yang digunakan untuk memberi makan hewan ternak.

\section{Presepsi Wisatawan Terhadap Pekarangan Rumah}

Berdasarkan hasil wawancara pada 10 responden wisatawan Desa Wisata Tambaksari diperoleh persepsi tentang pekarangan rumah. Tiga pertanyaan kuisioner dianalisis secara deskriptif, dan satu pertanyaan dianalisis mengunakan jawaban berjenjang. Responden menjawab semua pertanyaan yang diajukan dengan sangat antusias, sehingga tidak menyulitkan peneliti dalam memberi pertanyaanpertanyaan yang diajukan. Hasil persentase tentang kepentingan tanaman pekarangan rumah menurut wisatawan disajikan dalam Gambar 5.

Adanya tanaman pekarangan rumah dapat memberi fungsi ekologis yaitu oksigen selalu tersuplai dengan baik untuk lingkungan 
dan mencegah erosi tanah saat musim hujan. Jenis-jenis tanaman pekarangan dapat dipertahankan keberadaanya di pekarangan rumah Desa Wisata Tambaksari. Tanaman pangan, tanaman pakan ternak, tanaman obat adalah jenis tanaman yang sering dijumpai oleh wisatawan.

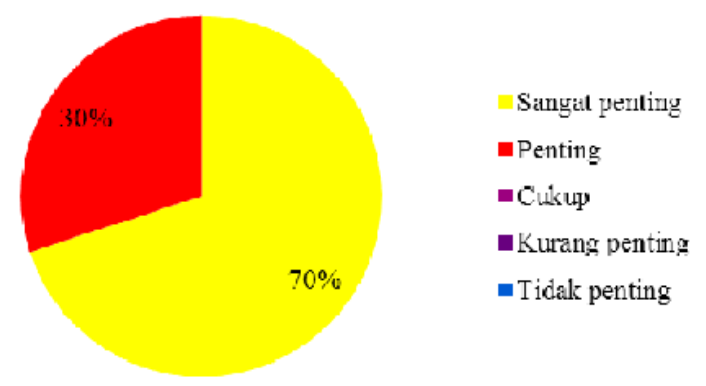

Gambar 5. Persentase Kepentingan Tanaman Pekarangan Rumah untuk Kegiatan Ekowisata Menurut Wisatawan

Wisatawan tidak menuntut pengelola desa wisata untuk menanam jenis-jenis tanaman yang tidak berada di Desa Wisata Tambaksari. Hal tersebut dikarenakan, masyarakat harus melestarikan jenis-jenis tanaman yang berada di desa wisata. Tanaman yang diperoleh adalah tanaman yang dimanfaatkan sehari-hari oleh responden termasuk tanaman liar yang jarang digunakan. Nilai UVs diperoleh dari akumulasi kegunaan bagian tanaman menurut responden.

Tabel 1. Jenis-jenis Tanaman yang Dijumpai Oleh Wisatawan.

\begin{tabular}{|c|c|c|c|c|c|}
\hline No. & $\begin{array}{c}\text { Nama } \\
\text { Lokal }\end{array}$ & Nama Ilmiah & No. & Nama Lokal & Nama Ilmia h \\
\hline 1. & Alpukat & $\begin{array}{c}\text { Persea gratissima } \\
\text { Gaertn. }\end{array}$ & 9. & Mbote & $\begin{array}{c}\text { Xanthosama } \\
\text { sagitiffolium (L.) } \\
\text { H.W. Schott \& Endl. }\end{array}$ \\
\hline 2. & Durian & $\begin{array}{c}\text { Durio zhibethinus } \\
\text { Murray. }\end{array}$ & 10. & $\begin{array}{c}\text { Rumput } \\
\text { gajah }\end{array}$ & $\begin{array}{c}\text { Pennisetum } \\
\text { purpureum } \\
\text { Schumach. }\end{array}$ \\
\hline 3. & Rambutan & $\begin{array}{c}\text { Nephelium lappaceum } \\
\text { L. }\end{array}$ & 11. & $\begin{array}{c}\text { Bambu } \\
\text { petung }\end{array}$ & Dendrocalamus asper \\
\hline 4. & Tomat & $\begin{array}{c}\text { Solanum lycopersicum } \\
\text { L. }\end{array}$ & 12. & Kopi & Coffea arabica L. \\
\hline 5. & Pisang & Musa p. & 13. & Sengon & Albizia falcataria \\
\hline 6. & Cabai rawit & $\begin{array}{c}\text { Capsicum frutescens } \\
\text { L. }\end{array}$ & 14. & Jagung & Zea mays L. \\
\hline 7. & Jahe & $\begin{array}{c}\text { Zingiber officinale } \\
\text { Rosc. }\end{array}$ & 15. & Langsep & $\begin{array}{c}\text { Lansium domesticum } \\
\text { Correa. }\end{array}$ \\
\hline 8. & Temulawak & $\begin{array}{c}\text { Curcuma xanthorrhiza } \\
\text { Roxb. }\end{array}$ & 16. & Kelengkeng & $\begin{array}{c}\text { Dimocarpus longan } \\
\text { Lour. }\end{array}$ \\
\hline
\end{tabular}

\section{Nilai UVs (Use Value)}

Berdasarkan hasil wawancara yang dilakukan pada 25 responden homestay dan 25 responden non homestay, didapatkan 43 jenis tanaman. 10 dari 43 tanaman pekarangan rumah yang mendapatkan nilai UVs tertinggi (Gambar 6). Terdapat 10 jenis tanaman pekarangan rumah yang mendapat nilai UVs 5 sampai dengan 2 . Tanaman-tanaman tersebut memiliki manfaat bagian tanaman terbanyak dari 43 jenis tanaman pekarangan yang diperoleh.

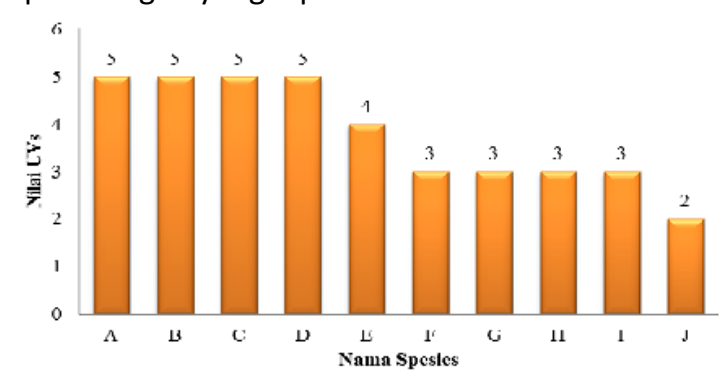

Keterangan: A. Musa acuminata var Berlin; B. Musa (Kelompok AA) Sucrier; C. Musa (Kelompok AAA) Gros Michael; D. Musa acuminata var Hijau; E. Dendrocalamus asper Backer.; $\boldsymbol{F}$. Syzygium aromatica (L) merr \& perry; G. Manihot esculenta Crantz.; H. Colocasia esculenta (L) Schott.; I. Cocos nucifera L.; J. Durio zhibethinus Murray.

Gambar 6. Sepuluh Tanaman (dari 43 tanaman) Dengan Nilai UVs Tertinggi

Tanaman pisang merupakan tanaman yang memiliki masa pertumbuhan cukup cepat dan terus menerus, yang berakibat pada hasil yang cukup tinggi. Buah pisang dapat dimanfaatkan dalam keadaan mentah maupun matang. Air yang keluar dari pangkal pelepah dapat disuntikkan untuk pengobatan penyakit disentri, raja singa, dan diare [5]. Pertumbuhan tanaman pisang yang cukup cepat adalah salah satu faktor banyaknya tanaman tersebut di Desa Wisata Tambaksari.

\section{Nilai ICS (Index of Cultural Significance)}

Berdasarkan hasil wawancara pada 25 responden homestay dan 25 responden non homestay serta didukung oleh persepsi peneliti didapatkan nilai ICS tanaman pekarangan rumah dari 43 jenis tanaman. Nilai ICS diperoleh dari persepsi peneliti menurut kepentingan penggunaan tanaman oleh responden. Kebanyakan dari tanaman merupakan tanaman musiman dan kelebihan hasilnya diperjual belikan. Faktor tersebut juga dapat mempengaruhi nilai ICS yang diperoleh peneliti.

Jenis-jenis tanaman yang memiliki nilai ICS tertinggi adalah tanaman yang memiliki nilai kegunaan lebih dari 3 manfaat. Selain itu tanaman tersebut sering digunakan oleh masyarakat untuk memenuhi kebutuhan. Nilai ICS yang diperoleh tergantung pada kegunaan tanaman, keseringan penggunaan, dan nilai ekslusivitas tanaman menurut masyarakat. Penilaian indeks ICS berdasarkan gabungan persepsi peneliti dan masyarakat, sehingga 
diketahui kepentingan penggunaan tanaman pada suatu daerah.

Kelapa (Cocos nucifera L.) mendapat nilai ICS tertinggi pertama karena kelapa dimanfaatkan dalam berbagai hal salah satunya pada bagian janur kelapa digunakan sebagai bungkus makanan ketupat (Gambar 7). Tanaman tomat (Solanum lycopersicum L.) juga mendapat nilai ICS tinggi dikarenakan, hampir setiap hari masyarakat memanfaatkanya untuk berbagai kebutuhan memasak. Tomat biasanya digunakan untuk melengkapi pembuatan bumbu dapur para ibu-ibu. Jenis-jenis tanaman tersebut sering dimanfaatkan oleh responden dalam kehidupan sehari-hari, sehingga memperoleh nilai ICS yang cukup tinggi. Meskipun tanaman bukan tanaman pokok, namun kegunaan yang cukup banyak dari tanaman tersebut mempengaruhi nilai yang diperoleh.

Pelestarian tanaman yang dilakukan oleh suatu masyarakat dapat mempertahankan keberadaan tanaman pada suatu daerah. Selain itu, dapat dilakukan pemanfaatan secara berkelanjutan dan secara tidak langsung melakukan konservasi tanaman-tanaman tersebut. Apabila hal ini dilakukan, maka kekhawatiran tentang hilangnya suatu jenis tanaman tidak perlu terjadi, karena adanya usaha pelestarian oleh masyarakat sekitar (Astuti dan Munawaroh, 2002).

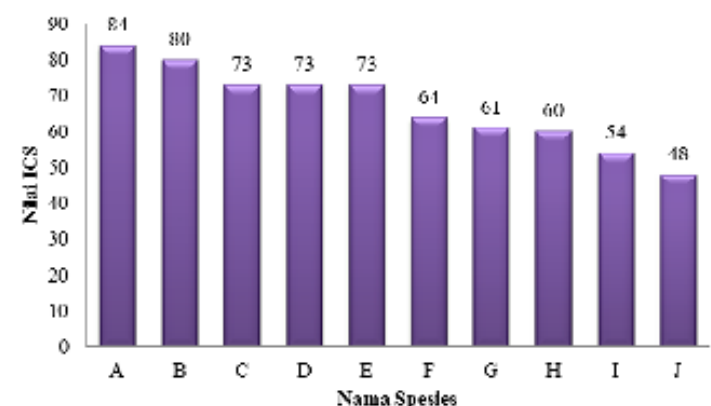

Keterangan: A. Cocos nucifera L.; B. Solanum lycopersicum L.; C. Musa acuminata var Berlin; D. Musa (Kelompok AA) Sucrier; E. Musa (Kelompok AAA) Gros Michael; F. Coffea arabica L.; G. Musa acuminata var Hijau; H. Dendrocalamus asper Backer.; I. Capsium frutescens L.; J. Zingiber officinale Rosc

Gambar 7. Sepuluh Tanaman (dari 43 tanaman) Dengan Nilai ICS Tertinggi

\section{Tabel Periodesitas Masa Panen dan Masa berbunga}

Berdasarkan hasil wawancara pada 50 responden homestay dan non-homestay diperoleh, masa panen dan masa berbunga 43 jenis tanaman pekarangan rumah di Desa Wisata
Tambaksari. Responden menyatakan bahwa satu jenis tanaman pekarangan rumah yang ditanam memiliki masa panen dan masa berbunga hampir bersamaan dalam satu desa. Periodesitas masa panen dan masa berbunga, disini berbeda dengan nilai periodesiats pada umumnya. Periodesitas masa panen dan berbunga hanya digunakan untuk mengetahui masa panen dan masa berbunga tanaman di desa wisata. Pembuatan tabel periodesitas ini nantinya dapat memudahkan wisatawan dalam kegiatan ekowisata. Tabel periodesitas masa panen dan berbunga dapat dijadikan sebagai acuan kegiatan ekowisata untuk memenuhi kebutuhan konsumsi maupun atraksi wisata secara visual. Hasil dari tabel periodesitas masa panen dan masa berbunga dapat dilihat pada Tabel 2 dan Tabel 3 (Lampiran).

Tabel dengan warna biru menyatakan bahwa, pada bulan tersebut tanaman pekarangan rumah mengalami masa panen dan masa berbunga, sehingga banyak dijumpai buah maupun hasil tanaman lainnya yang dapat dimanfaatkan atau dinikmati secara visual. Masa panen tanaman dikelompokan berdasarkan kelompok tanaman pohon, herba, perdu, dan liana. Pengelompokan tanaman dapat memudahkan wisatawan untuk mengetahui jenis-jenis tanaman berdasarkan kelompok tanaman, serta masa panen dan masa berbunga tanaman pekarangan rumah.

Pengelompokan tanaman berupa pohon adalah jenis-jenis tanaman berkayu keras seperti kelapa, sengon, dan durian. Tanaman berupa perdu adalah jenis tanaman berkayu lebih lunak dibandingkan tanaman pohon, contohnya adalah bunga singkong, kopi, dan bambu petung. Tanaman herba adalah jenis tanaman yang lebih rendah dibandingkan perdu dan tidak berkayu, contohnya adalah pisang berlin, rumput gajah, mbote. Pengelompokan terakhir adalah liana yang merupakan pengelompokan tanaman yang tumbuh merambat pada tanaman lain misalnya adalah uwi, sirih, dan kacang panjang. Tabel periodesitas masa berbunga tidak dilakukan pengelompokan tanaman seperti pada tabel periodesitas masa panen. Hal ini, dikarenakan untuk tabel periodesitas masa berbunga dibuat untuk memberi informasi mengenai tumbuhnya bunga untuk kegiatan visual atraksi wisata.

Informasi tabel periodesitas masa panen dan masa berbunga, nantinya dapat digunakan dalam kegiatan ekowisata di Desa Wisata Tambaksari. Tabel periodesitas yang telah dibuat dapat digunakan oleh pengelola desa wisata 
untuk memberi pengetahuan tentang tanaman yang tumbuh di pekarangan rumah. Sehingga, memudahkan wisatawan untuk mendapat informasi mengenai tanaman pekarangan rumah pada saat melakukan kegiatan ekowisata.

\section{KESIMPULAN}

Pengetahuan responden homestay jauh lebih tinggi dibandingkan responden non homestay tentang desa wisata. Begitu pula untuk persepsi pekarangan rumah, responden homestay lebih antusias dalam menjawab pertanyaan yang diajukan. Antusias yang ditunjukkan karena pekarangan rumah responden homestay digunakan sebagai kegiatan ekowisata. Kepentingan tanaman pekarangan rumah juga ditunjukkan oleh persepsi wisatawan. Wisatawan menyatakan bahwa tanaman pekarangan rumah yang sudah ada harus tetap dipertahankan keberadaannya.

Analisis ICS dan UVs dapat digunakan untuk menggali persepsi tentang etnobotani pekarangan rumah dalam mempertahankan biodiversitas pekarangan rumah dan fungsi ekologis lingkungan. Tabel periodesitas masa panen yang diperoleh dapat mempermudah kegiatan ekowisata di Desa Wisata tambaksari.

\section{DAFTAR PUSTAKA}

[1] Affandi, O. 2002. Home Garden : Sebagai Salah Satu Sistem Agroforsetry Lokal. Fakultas Pertanian, Program Ilmu Kehutanan, Universitas Sumatera Utara. Sumatera Utara

[2] Astuti, Inggit P dan Esti Munawaroh. 2002. Nilai Guna Mentha arvensis Linn. Sebagai Tumbuhan Obat di Jawa dan Upaya Konservasinya di Kebun Raya Bogor. Prosiding Simposium Nasional II Tumbuhan Obat dan Aromatik. Pusat Konservasi Tumbuhan Kebun Raya Bogor-LIPI. Bogor

[3] Damanik J dan Helmut W. 2006. Perencanaan Ekowisata dari Teori ke Aplikasi. Pusat Studi Pariwisata (PUSPAR) UGM dan ANDI Yogyakarta. Yogyakarta

[4] Hakim, L dan Nakagoshi, N. 2007. Plant Species Composition in Home Garden in The Tengger Highland (East Java, Indonesia) and its Importance for Regional Ecotourism Planning, Hikobia 15: 23-36

[5] Verheij dan Coronel. R. 1997. PROSEA Sumber Daya Nabati Asia Tenggara 2 Buah- buahan yang Dapat Dimakan. PT Gramedia

Pustaka Utama Jakarta, Jakarta 